\title{
Probiotics protect the intestinal wall of morphological changes caused by malnutrition
}

\author{
JORGE F. DE AZEVEDO ${ }^{1}$, CATCHIA HERMES-ULIANA ${ }^{2}$, DIRLENE P. LIMA ${ }^{3}$, \\ DÉBORA M.G. SANT'ANA ${ }^{4}$, GILBERTO ALVES ${ }^{5}$ and EDUARDO J.A. ARAÚJO ${ }^{6}$ \\ ${ }^{1}$ Departamento de Ciências Biológicas, Faculdades Associadas de Ariquemes/FAAR, \\ Av. Capitão Silvio, 2738, Grandes Áreas, 78932-000 Ariquemes, RO, Brasil \\ ${ }^{2}$ Universidade Federal de Mato Grosso do Sul/UFMS, \\ Avenida Marcio Lima Nantes, s/n, Vila da Barra, 79400-000 Coxim, MS, Brasil \\ ${ }^{3}$ Programa em Ciência Animal, Universidade Paranaense/UNIPAR, \\ Praça Mascarenhas de Moraes, 4282, 87502-210 Umuarama, PR, Brasil \\ ${ }^{4}$ Departamento de Ciências Morfológicas, Universidade Estadual de Maringá/UEM, \\ Avenida Colombo, 5790, Jardim Universitário, 87020-900 Maringá, PR, Brasil \\ ${ }^{5}$ Departamento de Nutrição, Universidade Paranaense/UNIPAR, \\ Praça Mascarenhas de Moraes, 4282, 87502-210 Umuarama, PR, Brasil \\ ${ }^{6}$ Departamento de Histologia, Universidade Estadual de Londrina/UEL, \\ Rodovia Celso Garcia Cid, Km 380, Campus Universitário, 86051-980 Londrina, PR, Brasil \\ Manuscript received on May 28, 2013; accepted for publication on October 14, 2013
}

\begin{abstract}
This study sought to morphometrically analyze the jejunal wall of protein-malnourished rats administered a probiotic supplement. The sample consisted of recently weaned Wistar rats (Rattus norvegicus) distributed among four groups: animals given a commercial diet $(\mathrm{G} 1, \mathrm{n}=4)$; animals given the same ration as G1 plus a probiotic supplement $(\mathrm{G} 2, \mathrm{n}=4)$; animals given a $4 \%$ protein $\operatorname{diet}(\mathrm{G} 3, \mathrm{n}=4)$; and animals given the same ration as $\mathrm{G} 3$ plus a probiotic supplement $(\mathrm{G} 4, \mathrm{n}=4)$. After 12 weeks, part of the jejunum was harvested and subjected to routine histological processing. Transverse sections with a thickness of $3 \mu \mathrm{m}$ were stained with $\mathrm{HE}$, and histochemical techniques were used to assay for glycoconjugates, including staining with periodic acid-Schiff (PAS) + diastase, Alcian Blue (AB) solution at $\mathrm{pH} 2.5$, and Alcian Blue solution at $\mathrm{pH}$ 1.0. Morphometric analysis of the bowel wall showed that the probiotic culture used in this study induced hypertrophy of several layers of the jejunal wall in well-nourished animals and reduced the bowel wall atrophy usually observed in protein-malnourished animals. Neither malnutrition nor the use of probiotics altered the relationship between the number of goblet cells and the number of enterocytes.
\end{abstract}

Key words: bowel, digestive system, histology, morphometry, protein-energy malnutrition, small intestine.

\section{INTRODUCTION}

Malnutrition remains one of the most devastating problems worldwide, particularly in developing countries (Solis et al. 2002). In addition to the social

Correspondence to: Eduardo José de Almeida Araújo

E-mail:ejaaraujo@gmail.com causes that contribute to its prevalence, malnutrition can be a consequence of ageing and can also occur in hospitalised patients (Grover and Ee 2009).

Malnutrition affects multiple organs and is usually reflected in a loss of body weight (Torrejais et al. 1995, Meilus et al. 1998, Natali et al. 2000, 
Zanim et al. 2003). The morphological alterations induced by malnutrition have been thoroughly investigated. Studies using experimental proteinmalnutrition models have shown a decreased thickness of bowel wall layers, such as reductions of the mucosa (Rodrigues et al. 1985, Firmansyah et al. 1989, Torrejais et al. 1995, Natali et al. 2000, Brandão et al. 2003, Gurmini et al. 2005, Schoffen et al. 2005, De Azevedo et al. 2007, Hermes et al. 2008), enterocyte height (Brandão et al. 2003, De Azevedo et al. 2007, Hermes et al. 2008), villi height (Firmansyah et al. 1989, Natali et al. 2000, Gurmini et al. 2005), crypt depth (Firmansyah et al. 1989, Hermes et al. 2008), and muscular layer thickness (Torrejais et al. 1995, Natali et al. 2000, 2005, Brandão et al. 2003, De Azevedo et al. 2007).

Therefore, strategies to correct or reduce the damage caused by malnutrition must be investigated. Studies using probiotics have been performed for this purpose (Solis et al. 2002, Cano et al. 2002, Cano and Perdigón 2003, Dock et al. 2004a, b, Dock-Nascimento et al. 2007, Lima et al. 2012). Probiotics are live microorganisms that when administered in appropriate amounts, are beneficial to the health of the host's organism (O'Sullivan and O'Morain 2000). Probiotics exhibit an improved in vitro digestibility of starch and protein (Sindhu and Khetarpaul 2002). However, several zootechnical studies have reported controversial results regarding digestibility and increases in body mass in animals used for human consumption (Kamra et al. 1996, De Brito et al. 2005, Sanches et al. 2006, Budiño et al. 2006, Huaynate et al. 2006, Zanato et al. 2008). Additionally, several studies have shown that probiotics stimulate the immune system (Erickson and Hubbard 2000, Cano and Perdigón 2003, Villena et al. 2006, De Souza et al. 2007, Dewan et al. 2007, Kaburagi et al. 2007, Pitsouni et al. 2009), which could contribute to prevention or even treatment of bowel infection, which is another problem to consider in cases of malnutrition associated with anatomical and functional bowel disorders (Chandra 1992). In addition, other studies suggest that probiotics might contribute to the integrity of the intestinal barrier (Menningen and Bruewer 2009) and that they are efficacious in treating inflammatory bowel diseases (Resta-Lenert and Barrett 2009).

However, few studies have assessed the repercussions of probiotics regarding the morphology of the bowel wall in malnourished animals. Besides, the majority of them are restricted to describing alterations only of the mucosa (Allori et al. 2000, Cano et al. 2002, Dock et al. 2004a, b, Dock-Nascimento et al. 2007). Concerned with to entire wall strata from malnourished rats, Lima et al. (2012) analyzed the large intestine and realized that the growth deficit of colon was prevented in animals treated with probiotics. But there are no investigations about the morphology of the different small intestine wall strata from malnourished rats treated with probiotics. Therefore, this study consisted of a morphometric analysis of the jejunal wall strata in protein-malnourished rats administered a probiotic supplement.

\section{MATERIALS AND METHODS}

\section{ETHICS STATEMENT}

This study was approved by the Animal Experimentation Research Ethics Committee of UNIPAR (protocol 11732), which follows the rules of the Brazilian College of Animal Experimentation (Colégio Brasileiro de Experimentação Animal COBEA).

\section{EXPERIMENTAL DESIGN}

The sample consisted of 16 recently weaned (42.9 $\pm 1.8 \mathrm{~g}$ ) male Wistar rats (Rattus norvegicus), which were housed in individual cages kept in a controlled temperature room $\left(+/-25^{\circ} \mathrm{C}\right)$ with a 12-hour light-dark cycle. Food and water were provided ad libitum during the entire study.

The animals were randomly divided into four groups: $\mathrm{G} 1$ animals were given NUVILAB ${ }^{\circledR}$ ration for rodents $(n=4)$; G2 animals were given 
the same ration as G1 and a solution containing a probiotic supplement via gastric tube five times per week (from Monday to Friday) $(n=4)$; G3 animals were given a diet of which the protein content was reduced to $4 \%$, according to the protocol suggested by Araújo et al. (2005) $(n=4)$; and G4 animals were given the same ration as G3 plus a probiotic supplement, as described above $(n=4)$. Animals in G1 and G3 were also exposed to the stress caused by tube feeding but were also given $10 \%$ skimmed powdered milk (Molico ${ }^{\circledR}$, Nestlé) in an amount equivalent to $1 \%$ of the group's average body weight.

After 12 weeks, the animals were weighed following 12 hours of fasting and subjected to the following anaesthesia treatment (Pachaly et al. 2003): acepromazine (Acepran $\left.{ }^{\mathrm{TM}}\right)(1.26 \mathrm{~mL} / \mathrm{Kg})+$ $10 \%$ ketamine $(1.26 \mathrm{~mL} / \mathrm{Kg})+2 \%$ xylazine $(0.42$ $\mathrm{mL} / \mathrm{Kg})$ and $1 \%$ atropine $(0.22 \mathrm{~mL} / \mathrm{Kg})$ via an intramuscular route. A laparotomy was performed to remove the jejunum in all animals, and its length and width were measured using a millimetre ruler.

Probiotic Culture

The probiotic supplement used in this study was a commercial thermophilic probiotic culture (ABT4 - Chr Hansen, A/S Denmark) containing the following microorganisms: Lactobacillus delbrueckii ssp. bulgaricus, Streptococcus salivarius ssp. thermophilus, Bifidumbacterium bifidus, and Lactobacillus acidophilus. The culture was inoculated into skim powdered milk at a concentration of $10 \%$ of the total solids present previously sterilised by autoclaving. Then, the culture was incubated at $42^{\circ} \mathrm{C}$ for 48 hours. The final count was $10^{10}$ colonyforming units (CFUs)/mL. The probiotic culture was administered to the animals in an amount equivalent to $1 \%$ of the group's average weight.

MORPHOMETRIC ANALYSIS OF THE BOWEL WALL

A $3-\mathrm{cm}$ ring from the proximal area (close to the duodenojejunal flexure) of each harvested jejunum was fixed with Bouin's fixative for 2 hours, dehydrated in an ascending series of ethanol concentrations, cleared in xylol, and embedded in paraffin for subsequent sectioning into $3-\mu \mathrm{m}$ transverse sections, which were then stained with hematoxylin-eosin (HE); periodic acid-Schiff (PAS) + diastase solution to detect neuter mucins and labile sialomucins; Alcian blue (AB), $\mathrm{pH} 2.5$ to detect sialomucins and sulfomucins; and Alcian blue (AB), $\mathrm{pH} 1.0$ to detect sulfomucins, according to the protocol of Myers et al. (2008). Counterstaining with hematoxylin was performed in the techniques used to detect glycoconjugates (PAS and $\mathrm{AB}$ ).

Morphometric analysis of the bowel wall was performed using images of HE-stained sections captured by a digital camera (Moticam 2000, 2.0 Megapixel) coupled to a trinocular light microscope. Images captured with the $10 \mathrm{X}$ objective were used to measure villi height; with the $20 \mathrm{X}$ objective for total wall and mucosa thickness; and with the 40X objective for enterocyte height and the largest diameter of the nuclei, villi width, crypt depth, and submucosa and muscular layer thicknesses. A total of 80 uniformly distributed measurements were performed around the full bowel circumference of each animal's jejunum, totalling 320 measurements per group.

\section{QUANTITATIVE ANALYSIS}

The ratio of goblet cells to enterocytes was calculated. For this purpose, 16 images were captured with the 40X objective from slides of each bowel segment collected from each animal stained using each described histochemical technique. Thus, a total of 192 images of the samples stained with PAS + diastase solution, AB $\mathrm{pH} 2.5$, and $\mathrm{AB}$ pH 1.0 were assessed for each harvested bowel segment.

STATISTICAL ANALYSIS

The type of data distribution was assessed by means of the D'Agostino-Pearson or Shapiro 
test. Data with a normal distribution were described using the mean \pm standard deviation, and a Student's t-test was applied to compare independent samples between groups. Data that were not normal distributed were expressed as the median $\left(25^{\text {th }}\right.$ percentile $-75^{\text {th }}$ percentile $)$, and a comparison between the groups was performed using the Mann-Whitney test. Comparisons were performed between the following groups: G1 vs. G2; G1 vs. G3; G1 vs. G4; G2 vs. G4; and G3 vs. G4. Significance was established at a p-value lower than 0.05 in all statistical tests.

\section{RESULTS AND DISCUSSION}

At the end of the study, animals in G1 weighed $352.2 \pm 16.5 \mathrm{~g}, \mathrm{G} 2380.9 \pm 17.3 \mathrm{~g}, \mathrm{G} 3180.2 \pm 13.4 \mathrm{~g}$, and G4 190.3 $\pm 9.4 \mathrm{~g}$. As found in previous studies (Torrejais et al. 1995, Natali et al. 2000, Araújo et al. 2005, De Azevedo et al. 2007, Hermes et al. 2008), weight gain in protein-malnourished animals was lower than in well-nourished animals $(p<0.001)$. It is worth noting that well-nourished animals administered the probiotic supplement $(\mathrm{G} 2)$ exhibited an $8.2 \%$ greater weight gain compared to well-nourished animals without the supplement (G1) $(\mathrm{p}<0.05)$. In another study using rats, Ferreira et al. (2006) failed to find any contribution of a probiotic supplement to weight gain. This difference might be because the previous study used adult animals and a single genus probiotic culture (Lactobacillus sp.). In contrast, the present study used a combination of several probiotic species, which were administered on a daily basis via gastric tube to recently weaned animals. However, when compared to malnourished animals not given the supplement, the probiotics administered to malnourished animals in the present study did not affect their weight gain ( $p>0.05)$, which is in accordance to the results reported by Cano et al. (2002) and Dock et al. (2004a, b).

TABLE I

Mean \pm standard deviation of the length, width, and area of the jejunum of rats subjected to protein malnutrition and administered a probiotic supplement.

\begin{tabular}{ccccr}
\hline Measures & G1 & G2 & G3 & G4 \\
\hline Length $(\mathrm{cm})$ & $96.75 \pm 10.63$ & $102.25 \pm 9.54$ & $88.00 \pm 11.63$ & $100.50 \pm 8.66$ \\
Width $(\mathrm{cm})$ & $1.03 \pm 0.13$ & $0.93 \pm 0.10$ & $0.80 \pm 0.24$ & $1.00 \pm 0.16$ \\
Area $\left(\mathrm{cm}^{2}\right)$ & $98.40^{\mathrm{a}} \pm 7.13$ & $95.00 \pm 16.87$ & $69.58^{\mathrm{b}} \pm 20.74$ & $99.90 \pm 13.22$ \\
\hline
\end{tabular}

G1: Commercial diet for rodents; G2: commercial diet + probiotic supplement; G3: 4\% protein chow; G4: 4\% protein chow + probiotic supplement. Comparison between groups (G1 vs. G2, G1 vs. G3, G1 vs. G4, G2 vs. G4, and G3 vs. G4) was performed by applying a Student's t-test for independent samples with $\alpha=0.05$. Means followed by different letters indicate significant differences at $\alpha=0.05$.

The results obtained from measurements of the harvested specimens of the jejunum are described in Table I. G3 animals exhibited a significantly $(p<0.05)$ lower bowel area compared to G1, which was expected because the animals in G1 were well nourished and those in G3 were malnourished. It is worth noting that the dimensions of the jejunum in animals that were administered the probiotic supplement (G2 and G4) did not show alterations, which corroborates the hypothesis that these microorganisms contribute to the animals' health.
Bowel area reduction was previously observed in the ileum (De Azevedo et al. 2007) and colon (Hermes et al. 2008) of malnourished rats in studies using the same protocol for malnutrition induction. Other experimental investigations of nutrition employing different protocols to induce protein malnutrition also detected atrophy of segments of the small bowel in rats (Da CostaRibeiro et al. 1987, Firmansyah et al. 1989, Meilus et al. 1998, Torrejais et al. 1995, Natali et al. 2000, 2005, Brandão et al. 2003). 


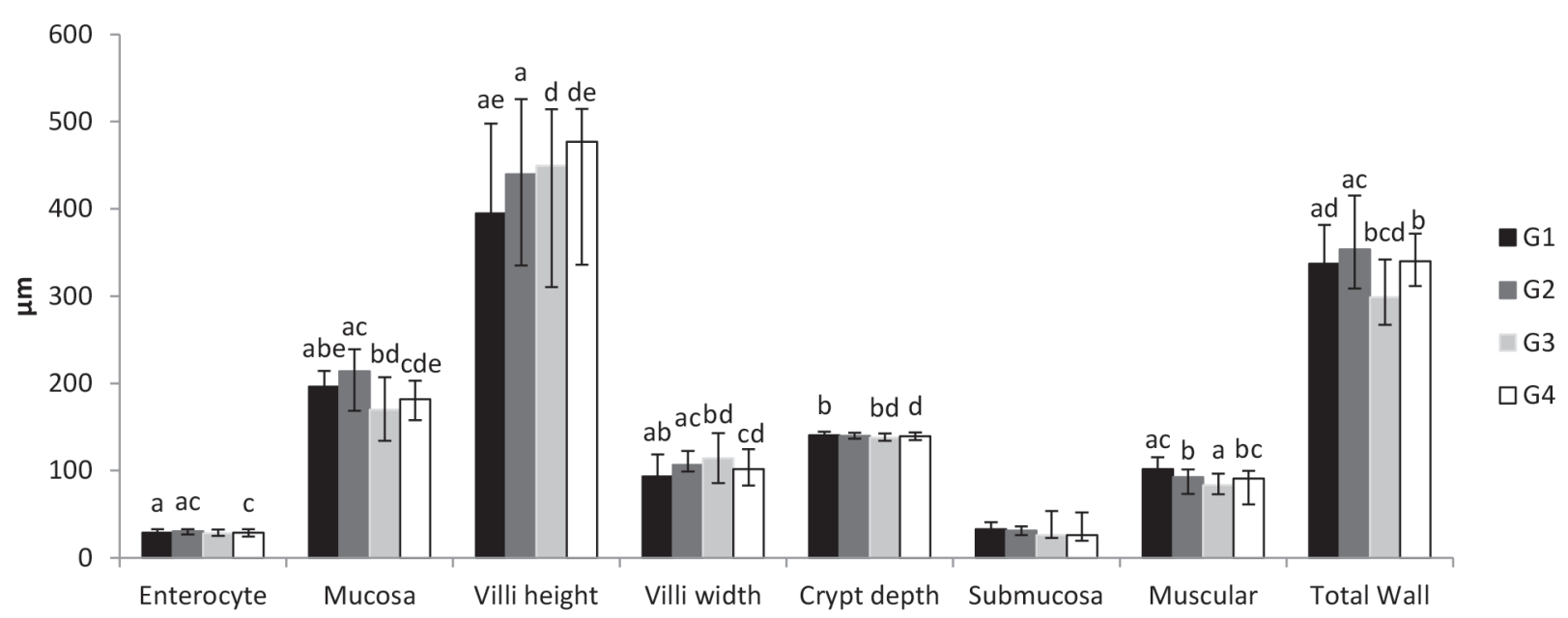

Figure 1 - Morphometric analysis of jejunal wall of rats submitted to protein restriction and supplemented with probiotics. The enterocytes are expressed by their height. The mucosa, submucosa, muscular and total wall are expressed by their thickness. G1: Commercial diet for rodents; G2: commercial diet + probiotic supplement; G3: 4\% protein chow; G4: 4\% protein chow + probiotic supplement. Columns followed by the same letter are significantly different. Comparisons between groups (G1 vs. G2, G1 vs. G3, G1 vs. G4, G2 vs. G4, and G3 vs. G4) were performed using the Mann-Whitney test with $\alpha=0.05$.

The morphometric analysis of the jejunal wall (Figure 1) showed that enterocyte height increased by $5.1 \%$ in animals in $\mathrm{G} 2$ compared to $\mathrm{G} 1(\mathrm{p}<0.05)$. This analysis indicates that the presence of probiotics in the bowel lumen probably triggers alterations in the cytoplasm of enterocytes that increase their longest axis, which in turn, increases the distance between the bowel microbiota and the bloodstream at the level of the adjacent lamina propria. Because there was no significant difference in enterocyte height between G4 and G1 ( $>00.05)$, whereas there was a decrease in this parameter between G4 and G2 $(p<0.05)$, it might be inferred that stimulation of the enterocytes by probiotics does not occur or is not maintained when the dietary availability of protein is low. The enterocytes are located at the interface between the lumen contents and the bowel mucosa and represent one of the main components of the intestinal barrier. Some studies have shown that several species of probiotic bacteria contribute to the integrity of the intestinal barrier, possibly by activating the expression of genes for proteins present in the occluding junctions (Mennigen and Bruewer 2009).
The mucosa thickness decreased in G3 animals compared to G1 animals $(p<0.05)$, which has also been observed in other studies (Viteri and Schneider 1974, Rodrigues et al. 1985, Da CostaRibeiro et al. 1987, Torrejais et al. 1995, Natali et al. 2000, Schoffen et al. 2005, De Azevedo et al. 2007, Hermes et al. 2008). Conversely, the mucosa was less reduced in G4 (7.4\%) than in G3 (13.5\%) compared to well-nourished G1 animals $(\mathrm{p}<0.05)$, as illustrated in Figure 2. Thus, the probiotics contributed to minimising the loss of the mucosa, which is a frequent occurrence in malnutrition. This loss-of-mucosa phenomenon might be better understood when considering that the mucosa of G2 animals was thicker when compared to those of G1 $(p<0.05)$. This finding corroborates the role of probiotics as trophic mucosa stimulants suggested by Aguilar-Nascimento et al. (2006) based on other experiments performed with malnourished animals (Dock et al. 2004a, Aguilar-Nascimento et al. 2006, Dock-Nascimento et al. 2007), which has been proposed to involve modulating enterocytes and/ or increasing the number of immune system cells (dendritic cells, macrophages, B and T lymphocytes, 

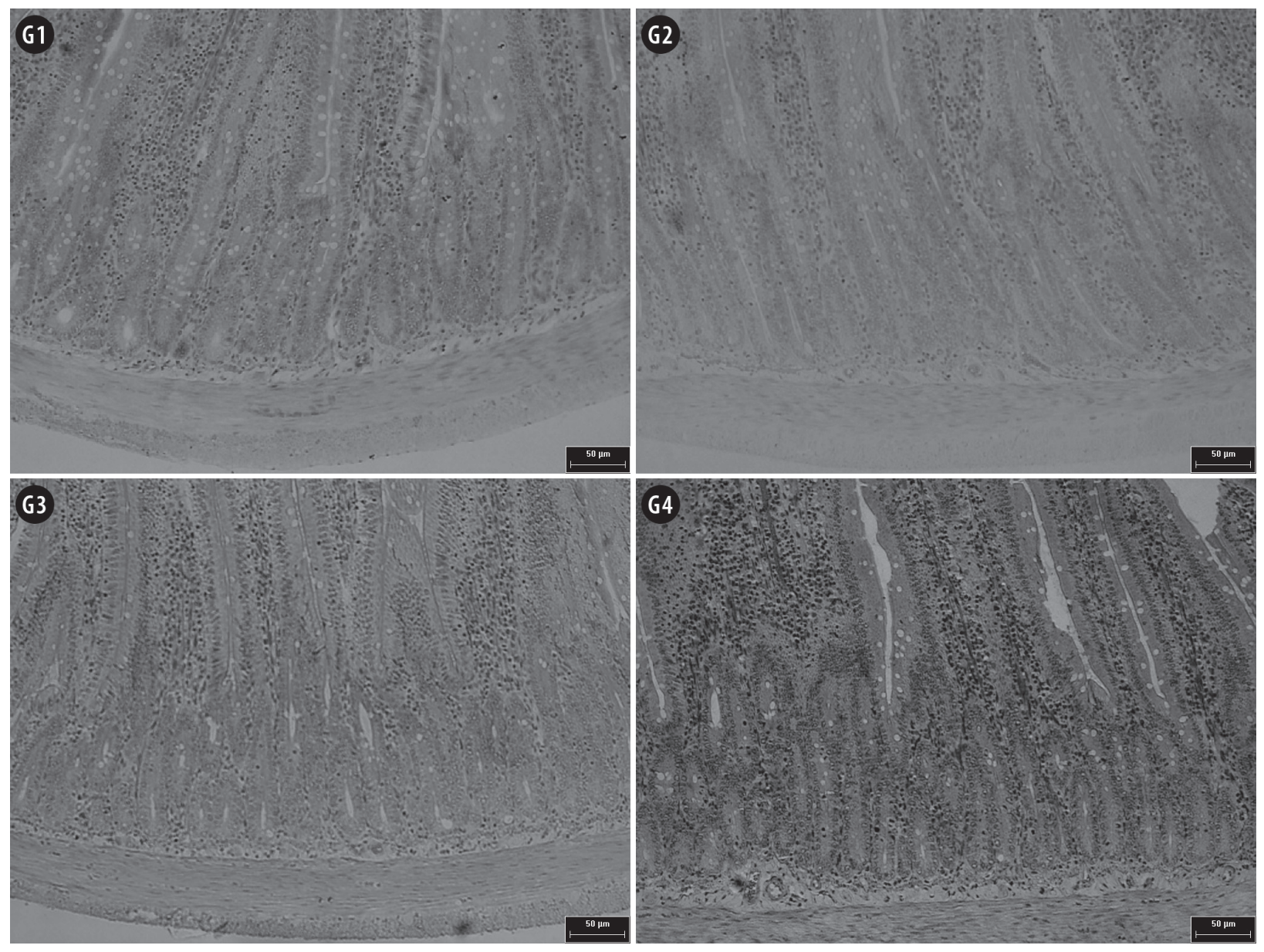

Figure 2 - Photomicrographs of jejunal mucosa of rats submitted to protein restriction and supplemented with probiotics. G1: Commercial diet for rodents; G2: commercial diet + probiotic supplement; G3: 4\% protein chow; G4: 4\% protein chow + probiotic supplement. Stained with hematoxylin and eosin. Scale bar $=50 \mu \mathrm{m}$.

and natural killer cells) in the lamina propria ( $\mathrm{Ng}$ et al. 2009). Contrary to this hypothesis, Ferreira et al. (2006) used a probiotic Lactobacillus genus culture and did not find changes in the thickness of the mucosa. However, these authors added the probiotics to the feed, which might have impaired the microorganisms' viability. Additionally, this last study differs from the current one because it lasted only 40 days and employed adult animals.

Regarding the structures of the mucosa, the animals in the groups administered the probiotic supplement (G2 and G4) exhibited an increase of villi height $(p<0.05)$, independent of their nutritional status, i.e., independent of whether they were well nourished (G2) or malnourished (G4). This finding allows the inference to be made that in animals with taller villi, nutrient absorption was probably greater as a function of the increased contact surface between the bowel wall and the lumen. Because probiotics contribute to the integrity of the bowel epithelium ( $\mathrm{Ng}$ et al. 2009, Resta-Lenert and Barrett 2009), appropriate positioning of enterocytes probably contributed to better digestion of peptides. Consequently, the presence of a larger absorption surface might lead to a state closer to that of homeostasis, especially under conditions where the dietary protein supply is lower than the organic requirements. If this hypothesis is true, it might help 
to explain the greater weight gain of animals in G2 compared to G1 as well as the similar tendency observed in G4 compared to G3. Biochemical studies assessing the activity of peptidases located in the enterocyte villi must be performed to understand the actual mechanism involved in this scenario. Conversely, villi width exhibited heterogeneous behaviour because it increased in animals in G2 and G3 (compared to G1) and decreased in G4 (compared to G2 and G3) $(\mathrm{p}<0.05)$. Therefore, it can be inferred that the villi of well-nourished animals administered the probiotic supplement (G2) became taller and wider, whereas the villi of malnourished animals not given the probiotic supplement (G3) maintained the same height but became wider and those of malnourished animals given the probiotic supplement (G4) grew taller and thinner. Because the population density of the conjunctive tissue cells present in the lamina propria primarily determines villi width, further studies assessing the dynamics of these cells in malnourished animals receiving probiotic supplements must be performed in order to understand the observed increases in villi height/ width. This phenomenon is of paramount importance because probiotics stimulate the function of the gut-associated immune system ( $\mathrm{Ng}$ et al. 2009), probably leading to greater recruitment of immune system cells present in the bowel mucosa. The recruitment of immune system cells might explain the increased thickness of both the villi and the mucosa detected in G2 animals; however, in G4 animals, this mechanism was likely affected by the lower availability of dietary amino acids, which minimised the trophic effect of the probiotics on the immune system. $\mathrm{Ng}$ et al. (2009) however, suggest that stimulation of the immune system by probiotics depends on the availability of dietary amino acids. The gaps in the current understanding of the mechanisms involved in probiotics stimulation must be cautiously investigated, as both the probiotics themselves and the host species are significant variables in this interaction (Verdu 2009). Broiler chicks administered different probiotic formulations also exhibited an increase of bowel villi height, but only in the duodenum, whereas the jejunum and ileum did not exhibit significant differences (Pelicano et al. 2003).

Crypt depth decreased in malnourished animals not given the probiotic supplement (G3), probably due to the reduction of mucosa thickness. In the malnourished animals administered the probiotic supplement $(\mathrm{G} 4)$, the crypts were similar to those in well-nourished animals $(\mathrm{p}<0.05)$. These findings show that the probiotics succeeded in protecting the crypts from the depth reduction caused by the lower availability of exogenous amino acids. Because bowel epithelium renewal begins in the crypts and because the crypts contain different types of cells that are directly involved in bowel homeostasis (Paneth cells, neuroendocrine cells, and goblet cells) (Junqueira and Carneiro 2008), this study suggests that probiotics probably contributed to maintaining epithelium renewal activity; however, further investigations are required to understand the mechanisms involved in this process. Broiler chicks administered a probiotic supplement consisting of the species Bacillus subtilis and $B$. licheniformis exhibited an increase of the crypt depth in the duodenum, jejunum, and ileum (Pelicano et al. 2003). This difference from the findings of the present study again shows that comparison between studies using probiotics must be addressed very carefully and must consider the microorganism and host species involved.

The submucosa was the only bowel wall layer that did not show changes in any group. Because the submucosa is composed of dense irregular conjunctive tissue that is rich in collagen and elastic fibres (Junqueira and Carneiro 2008), the results of the present study suggest that the area occupied by these fibres did not change in response to the applied experimental treatments. However, histochemical analyses of conjunctive tissue fibres must be performed using an experimental model similar 
to the one used in this study to establish whether there is any qualitative or quantitative alteration of the molecules in this bowel wall layer. It might be inferred that there is a tendency to preserve the proteins constituting the collagen and elastic fibres under conditions of protein malnutrition, though this is the opposite of what is observed with respect to the behaviour of the conjunctive tissue fibres in the dermis of malnourished animals and humans (Waterlow 1996). It could also be inferred that the presence of probiotics in the bowel lumen does not cause alterations in the submucosa. The submucosa is not commonly measured in morphometric assessments of the bowels of malnourished animals (Natali et al. 2000, De Azevedo et al. 2007, Hermes et al. 2008). A single study measured the submucosa in the jejunum of malnourished rats using the same protocol as that applied in the present study and did not find alterations in the submucosa thickness (Franco et al. 2010). Torrejais et al. (1995) measured the submucosa in the ileum of rats fed a ration containing $8 \%$ protein and reported a reduction of the submucosa; however, this result was based exclusively on a qualitative assessment. No previous study has assessed the influence of probiotics on the submucosa.

The muscular thickness decreased in all malnourished animals in the present study; however, the decrease was smaller (10.7\%) in animals administered the probiotic supplement compared to animals not given the supplement $(18.0 \%)(\mathrm{p}<0.05)$, as shown in Figure 3. Other experimental studies using the same protocol for protein-malnutrition induction as applied in the current study found a $58.9 \%$ reduction of the muscular layer in the ileum (De Azevedo et al. 2007), while Hermes et al. (2008) found no change in the colon. In addition, muscular layer atrophy has been observed in the duodenum (Natali et al. 2000) and ileum (Torrejais et al. 1995) of rats fed a ration containing $8 \%$ protein. These results indicate that this small bowel wall layer is quite susceptible to protein malnutrition, probably due to a mechanism similar to the one that occurs in skeletal muscle, making endogenous amino acids available to compensate for low dietary supplies (Waterlow 1996, Araújo et al. 2005). Because the malnourished animals that received the probiotic supplement exhibited less loss of muscular mass in the jejunum, the present study suggests that the presence of the microorganisms led to a higher accessibility of dietary amino acids, which probably reduced the protein depletion in the animals' muscular tissue. This function is likely due to the ability of probiotics to enhance the integrity of the intestinal barrier and to promote the inflow of nutrients from the bowel lumen (Resta-Lenert and Barrett 2009).

Most of the investigated jejunal wall parameters exhibited increases in the well-nourished animals that were administered the probiotic supplement (G2). The total thickness of the wall increased by $5.0 \%$ compared to the animals in G1 $(\mathrm{p}<0.05)$. However, in malnourished animals that received the probiotic supplement (G4), some components of the bowel wall increased, while others decreased. Thus, the total bowel wall thickness did not exhibit a significant difference compared to well-nourished animals (G1). In malnourished animals that did not receive the probiotic supplement (G3), almost all parameters showed decreases, and atrophy of the total jejunal wall thickness was observed $(p<0.05)$. De Azevedo et al. (2007) observed a similar atrophy in the ileum of rats subjected to the same malnutrition induction protocol used in this study. Malnourished rats fed a ration containing $8 \%$ protein also exhibited atrophy of the duodenal (Natali et al. 2000) and the ileum walls (Torrejais et al. 1995). Therefore, it is evident that protein malnutrition causes bowel wall atrophy and that the probiotics used in this study were able to prevent atrophy in the supplemented animals. Dock et al. (2004b) used the probiotics Streptococcus thermophilus and Lactobacillus helveticus and found that the microorganisms contributed to a faster recovery from bowel atrophy caused by malnutrition, which is in agreement with the current findings. 

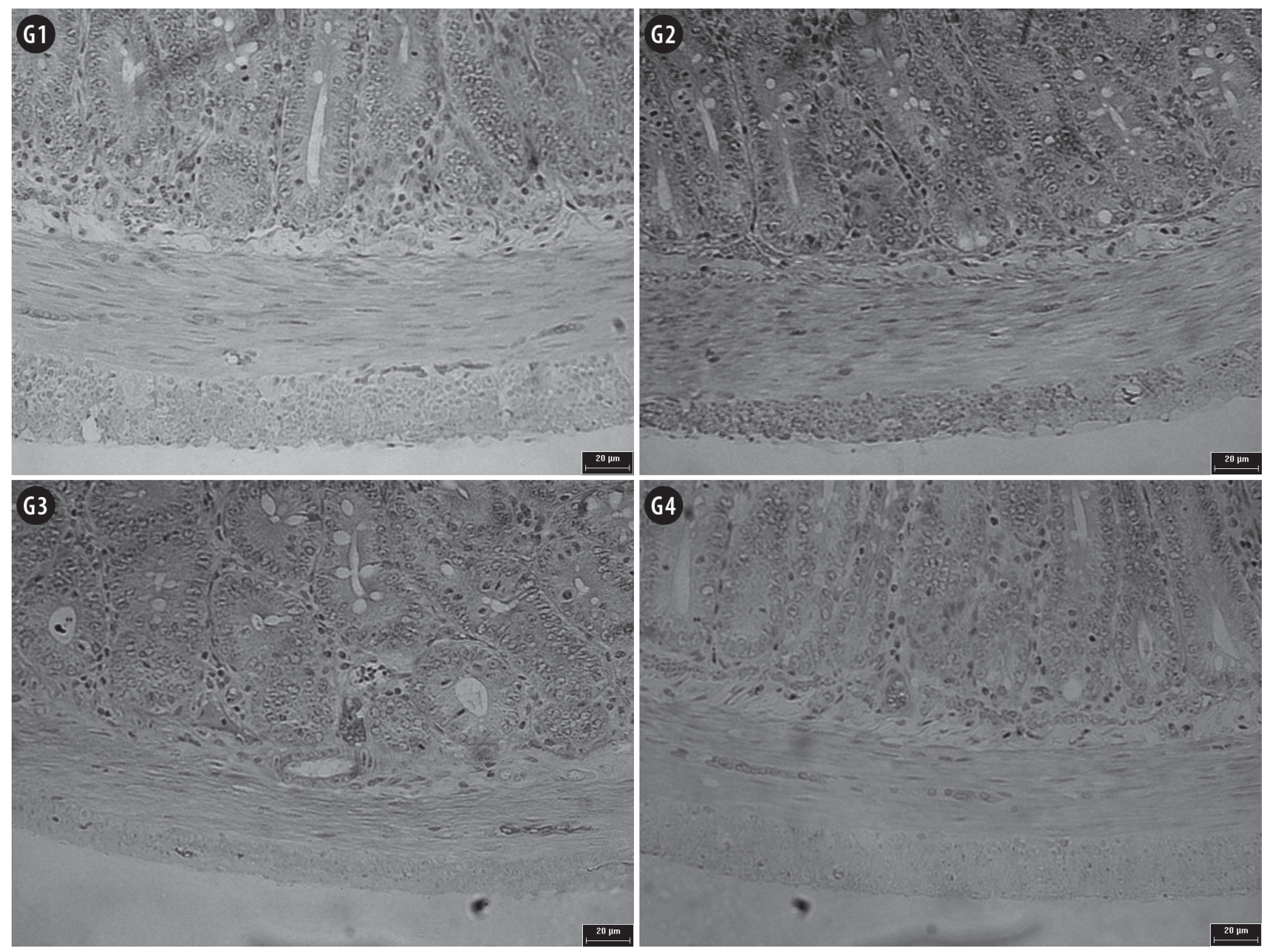

Figure 3 - Photomicrographs of jejunal muscular layer of rats submitted to protein restriction and supplemented with probiotics. G1: Commercial diet for rodents; G2: commercial diet + probiotic supplement; G3: 4\% protein chow; G4: 4\% protein chow + probiotic supplement. Stained with hematoxylin and eosin. Scale bar $=20 \mu \mathrm{m}$.

TABLE II

Mean \pm standard deviation of goblet cell/enterocyte ratio in the jejunal mucosa of rats subjected to protein malnutrition and administered a probiotic supplement.

\begin{tabular}{ccccc}
\hline Technique & G1 & G2 & G3 & G4 \\
\hline PAS + diastase solution & $0.14 \pm 0.02$ & $0.14 \pm 0.03$ & $0.15 \pm 0.03$ & $0.14 \pm 0.02$ \\
AB pH 2.5 & $0.15 \pm 0.02$ & $0.13 \pm 0.02$ & $0.14 \pm 0.04$ & $0.15 \pm 0.01$ \\
AB pH 1.0 & $0.14 \pm 0.02$ & $0.14 \pm 0.01$ & $0.14 \pm 0.01$ & $0.15 \pm 0.02$ \\
\hline
\end{tabular}

G1: Commercial diet for rodents; G2: commercial diet + probiotic supplement; G3: 4\% protein chow; G4: 4\% protein chow + probiotic supplement. PAS: Periodic acid-Schiff; AB: Alcian blue. Comparisons between groups (G1 vs. G2, G1 vs. G3, G1 vs. G4, G2 vs. G4, and G3 vs. G4) were performed by applying a Student's t-test for independent samples with $\alpha=0.05$. There is no significant difference between the groups.

The ratio of goblet cells to enterocytes remained unaltered among the study groups, independent of the histochemical technique employed in the analysis (Table II). This result demonstrates that neither malnutrition nor probiotics affected the relationship between the number of goblet cells and the number of enterocytes or the proportions of neuter mucins, sialomucins, and sulfomucins secreted by the goblet cells. Furthermore, this lack of an effect suggests that neither malnutrition 
nor probiotics modified the chemical nature of the mucus coating the jejunal epithelium of the animals. In other studies applying the same malnutrition induction protocol, the number of goblet cells that are reactive to $\mathrm{AB} \mathrm{pH} 1.0$ was found to increase in the jejunum (Franco et al. 2010), whereas the number of cells reactive to PAS and $\mathrm{AB}$ pH 2.5 in the colon decreases (Hermes et al. 2008). This difference compared to the results of the present study might be related to how the cells were counted, but it could also be because the two previous studies were performed with adult rats, whereas the present study used weaned animals. In addition, none of the groups that received the probiotic supplement (G2 and G4) exhibited any alteration of the depth of crypts, which are the sites where both enterocytes and goblet cells originate, and this might also be related to the results found for the ratio of the two cell types. Generally, probiotics increase the secretion of mucins and, thus, increase the mucus layer coating the epithelium; however, this increase in secretion was observed in studies performed in the colon (Caballero-Franco et al. 2007), including in animals with experimentally induced malnutrition (Dock-Nascimento et al. 2007).

The authors conclude that the probiotic culture used in the present study induced hypertrophy of several layers of the jejunal wall in well-nourished animals and minimised the atrophy usually observed in the bowel wall of protein-malnourished animals. In addition, neither malnutrition nor the probiotic supplement altered the relationship between the number of goblet cells and the number of enterocytes. These findings suggest that the use of probiotics might minimise the bowel damage usually associated with protein malnutrition.

\section{ACKNOWLEDGMENTS}

This study was supported by Universidade Paranaense (UNIPAR), Brazil. The funder had no role in the design, data collection and analysis, decision to publish, or preparation of the manuscript.

\section{RESUMO}

Objetivou-se analisar morfometricamente a parede do jejuno de ratos desnutridos proteicamente e suplementados com probióticos. Para tanto, 16 ratos (Rattus norvegicus) Wistar recém-desmamados foram distribuídos em quatro grupos: animais que receberam a dieta comercial $(\mathrm{G} 1, \mathrm{n}=4)$; animais que receberam a mesma ração do grupo G1 e que foram suplementados com probióticos $(\mathrm{G} 2, \mathrm{n}=4)$; animais que receberam uma dieta de com $4 \%$ de proteínas $(\mathrm{G} 3, \mathrm{n}=4)$; animais que receberam a mesma ração do grupo $\mathrm{G} 3$ e que foram suplementados com probióticos $(\mathrm{G} 4, \mathrm{n}=4)$ ). Após 12 semanas, parte do jejuno foi coletada e submetida à rotina de processamento histológico. Cortes transversais de 3 $\mu \mathrm{m}$ foram corados com HE e técnicas histoquímicas para evidenciação de glicoconjugados: Periodic Acid Schifff (PAS) + solução de diástase e Alcian Blue (AB) pH 2,5 e pH 1,0. A análise morfométrica da parede intestinal revelou que a cultura probiótica utilizada neste estudo provocou hipertrofia de vários estratos da parede jejunal de animais normonutridos e diminuiu a atrofia normalmente observada na parede intestinal de animais desnutridos proteicamente. Além disso, a desnutrição e o uso de probióticos não alteraram a relação entre o número de células caliciformes e o número de enterócitos.

Palavras-chave: intestino, sistema digestório, histologia, morfometria, desnutrição protéico-energética, intestino delgado.

\section{REFERENCES}

Aguilar-Nascimento JE, Padro S, ZafFani G, Salomão AB, Neves JS, DOCK-NASCIMENTO DB, MELlo PRB AND OKAY TS. 2006. Perioperative administration of probiotics: effects on immune response, anastomotic resistance and colonic mucosal trophism. Acta Cirur Bras 21: 80-83.

Allori C, Aguero G, De Ruiz-Holgado AP, Nader OM AND PERDigÓn G. 2000. Gut mucosa morphology and microflora changes in malnourished mice after renutrition with milk and administration of Lactobacillus casei. J Food Prot 63: 83-90.

ARAÚJo EJA, SANT'ANA DMG, Molinari SL AND MirandA NeTO MH. 2005. Biometric and food consumption parameters of rats subjected to hypoproteic and hipercaloric diet. Arq Ciênc Vet Zool Unipar 8: 131-138. 
BRANDÃo MCS, DE ANGElis RC, De SouZa RR, Froes LB AND LIBERTI EA. 2003. Effects of pre and postnatal protein energy deprivation on the myenteric plexus of the small intestine: a morphometric study in weanling rats. Nutr Res 75: 7-15.

BudiÑo FEL, ThOMAZ MC, KRONKA RN, TUCCI FM, FragA AL, ScAndolera AJ, HuAYNATE RAR, NADAI A AND CORREIA RC. 2006. Efeito da adição de probiótico e/ ou prebiótico em dietas de leitões desmamados sobre o desempenho, incidência de diarréia e contagem de coliformes totais. Braz J Vet Res Anim 43: 59-67.

Caballero-Franco CK, Keller C, De Simone and Chadee K. 2007. The VSL\#3 probiotic formula induces mucin gene expression and secretion in colonic epithelial cells. Am J Physiol Gastrointest Liver Physiol 292: G315-G322.

CANo PG, AGOERo G AND PERdigón G. 2002. Adjuvant effects of Lactobacillus casei added to a renutrition diet in a malnourished mouse model. Biocell 26: 35-48.

CANO PG AND PERdigón G. 2003. Probiotics induce resistance to enteropathogens in a re-nourished mouse model. J Dairy Res 70: 433-440.

CHANDRA RK. 1992. Protein-energy malnutrition and immunological responses. J Nutr 122: 597-600.

Da Costa-Ribeiro HC, Teichberg S, McGarvey E AND LIFSHITZ F. 1987. Quantitative alterations in the structural development of jejunal absortive ephitelial cells and their subcellular organelles in protein-energy-malnourished rats: a stereologic analysis. Gastroenterol 93: 1381-1392.

De Azevedo JF, Hermes C, Manzano MA, AraúJo EJA AND SANT'ANA DMG. 2007. Análise morfométrica da parede intestinal do íleo de ratos submetidos a intensa carência de proteínas. Arq Ciênc Vet Zool Unipar 10: 85-89.

De Brito AB, LeAndro NSM, Stringhini JH, Bastos CAA, Cunha WP AND CAFÉ MB. 2005. Desempenho e digestibilidade de nutrientes para frangos alimentados com rações contendo promotor de crescimento (Olaquindox) e probiótico (Bacillus subtillis). Acta Sci 27: 327-332.

DE Souza MM, Aguilar-NASCIMENTO JE AND DockNASCIMENTO DB. 2007. Effects of budesonide and probiotics enemas on the systemic inflammatory response of rats with experimental colitis. Acta Cir Bras 22: 40-45.

DEWAN P, KaUR I, CHATTOPADHY AD, FARIDI MMA AND AGARWAL KN. 2007. A pilot study on the effects of curd (dahi) and leaf protein concentrate in children with protein energy malnutrition (PEM). Indian J Med Res 126: 199-203.

Dock DB, Aguilar-Nascimento JE AND LATORRACA MQ. 2004b. Probiotics enhance the recovery of gut atrophy in experimental malnutrition. Biocell 28: 143-150.

Dock DB, LATORRACA MQ, AgUILAR-NASCIMENTO JE AND GOMES-DA-SILVA MHG. 2004a. Probiotics enhance recovery from malnutrition and lessen colonic mucosal atrophy after short-term fasting in rats. Nutr 20: 473-476.

Dock-NASCIMENTO DB, Kelly J AND AgUIAR-NASCIMENTO JE. 2007. Rapid restoration of colonic goblet cells induced by a hydrolyzed diet containing probiotics in experimental malnutrition. Acta Cir Bras 22: 72-76.
ERICKSON KL AND HuBBARD NE. 2000. Probiotic immunomodulation in health and disease. J Nutr 130: 403S-409S.

FERrEIRA NF, CAVASIN-OliveIRA GM, Alves CB, NASCIMENTO MN AND OliveIRA EM. 2006. Efeito da utilização de probióticos a base de Lactobacillus sp. sobre o ganho de peso e desenvolvimento da mucosa intestinal de ratos (Rattus norvegicus). Ciênc Anim Bras 7: 217-222.

Firmansyah A, Suwandito L, Penn D and Lebenthal E. 1989. Biochemical and morphological changes in the digestive tract of rats after prenatal and postnatal malnutrition. Am J Clin Nutr 50: 261-268.

Franco CLM, SANT'ANA DMG AND ARAúJo EJA. 2010. Intestinal wall atrophy and increase of sulphomucin secretion in the jejunal epithelium of rats submitted to severe protein malnutrition. Int J Morphol 28: 497-502.

Grover Z AND Ee LC. 2009. Protein energy malnutrition. Pediatr Clin N Am 56: 1055-1068.

GuRmini J, CECÍlio WAC, Schuler SL, OlANDOSKI M AND DE NoRONHA L. 2005. Desnutrição intra-uterina e suas alterações no intestino delgado de ratos wistar ao nascimento e após a lactação. J Bras Patol Med Lab 41: 271-278.

Hermes C, Almeida EC, Souza EA, ARAúJo EJA AND SANT'ANA DMG. 2008. Efeitos da desnutrição protéica severa sobre aspectos morfológicos e quantitativos dos neurônios mientéricos do cólon ascendente de ratos. Arq Ciênc Vet Zool Unipar 11: 13-16.

HuAYnate RAR, Thomaz MC, Kronka RN, Fraga AL, SCANDOLERA AJ AND BUdiÑo FEL. 2006. Uso de probiótico em dietas de suínos: incidência de diarréia, desempenho zootécnico e digestibilidade de rações. Braz J Vet Res Anim Sci 43: 664-673.

JUNQUEIRA LC AND CARNEIRO J. 2008. Histologia Básica. $11^{\mathrm{a}}$ ed., Rio de Janeiro: Guanabara Koogan, 524 p.

Kaburagi T, Yamano T, Fukushima Y, Yoshino H, Mito N AND SATO K. 2007. Effect of Lactobacillus johnsonii La1 on immune function and serum albumin in aged and malnourished aged mice. Nutr 23: 342-350.

Kamra DN, Chaudhary LC, Singh R AND PATHAK NN. 1996. Influence of feeding probiotics on growth performance and nutrient digestibility in rabbits. World Rabbit Sci 4: 85-88.

Lima DP, AZEVEdo JFD, Hermes-Uliana C, Alves G, SANT'ANA DM AND ARAÚJO EJ. 2012. Probiotics prevent growth deficit of colon wall strata of malnourished rats post-lactation. An Acad Bras Cienc 84: 727-736.

Meilus M, NATALI MRM AND Miranda Neto MH. 1998. Study of the myenteric plexus of the ileum of rats subjected to proteic undernutrition. Revta Chil Anat 16: 9-14.

MENNINGEN R AND BRUEWER M. 2009. Effect of probiotics on intestinal barrier function. Ann NY Acad Sci 1165: 183:189.

Myers RB, Fredenburgh JL AND Grizzle WE. 2008. Carbohydrates. In: BANCROFT JD AND GAMBLE M (Eds), Theory and practice of histological techniques, Churchill Livingstone Elsevier: Philadelphia, USA, p. 161-186.

NATALI MRM, MirandA Neto MH AND ORSI AM. 2000. Effect of hypoproteic diet supply on adult Wistar on adult rats (Rattus Norvegicus). Acta Sci 22: 567-571. 
NATALI MRM, MOLINARI SL, VALENTINI LC AND MirAndA NETO MH. 2005. Morphoquantitative evaluation of the duodenal myenteric neuronal population in rats fed with hypoproteic ration. Biocell 29: 39-46.

NG SC, HART AL, Kamm MA, StaGG AJ AND KNIGHT SC. 2009. Mechanisms of action of probiotics: recent advances. Inflamm Bowel Dis 15: 300-310.

O'Sullivan MA AND O'MORAIn CA. 2000. Bacterial supplementation in the irritable bowel syndrome. A randomized double-blind placebo-controlled crossover study. Dig Liver Dis 32: 294-301.

PACHALY JR, SANT'ANA DMG, ARAúJo EJA, CiFFONI EMG AND ACCO A. 2003. Anestesia of Wistar rats (Rattus norvegicus) with allometrically scaled dose of Ketamine, Xylazine, Acepromazine and Atropine - preliminary report. Arq Ciênc Vet Zool Unipar 6: 195.

Pelicano ERL, Souza PA, Souza HBA, OBA A, Norkus EA, KODAWARA LM AND LIMA TMA. 2003. Morfometria da e ultra-estrutura da mucosa intestinal de frangos de corte alimentados com dietas contendo diferentes probióticos. Rev Port Ciências Veterinárias 98: 125-134.

Pitsouni E, AlEXIOU V, SARIDAKIS V, PEPPAS Gand FAlagas ME. 2009. Dos the use of probiotics/synbiotics prevent postoperative infections in patients undergoing abdominal surgery? A meta-analysis of randomized controlled trials. Eur J Clin Pharmacol 65: 561-570.

RESTA-LENERT SC AND BARRET KE. 2009. Modulation of intestinal barrier properties by probiotics: role in reversing colitis. Ann NY Acad Sci 1165: 175-182.

Rodrigues MAM, DE CAMARgo JLV, COElHo KIR, Montenegro MRG, ANGEline AYO AND Burini RC. 1985. Morphometric study of the small intestinal in young, adult, and old rats submitted to protein deficiency and rehabilitation. Gut 26: 816-821.

SANChES AL, Lima JAF, Fialho ET, MuRgas LDS, AlmeidA EC, VIEIRA-NETO J AND DE FreITAS RTF. 2006. Utilização de probiótico, prebiótico e simbiótico em rações de leitões ao desmame. Ciênc Agrotec 30: 774-777.
SCHOFFEn JPF, SoARES A, De Freitas P, ButTow NC AND NATALI MRM. 2005. Effects of a hypoproteic diet on myosin-V immunostained myenteric neurons and the proximal colon wall of aging rats. Auton Neurosci 122: 77-83.

SiNDHU SC AND KHETARPAUL N. 2002. Effect of probiotic fermentation on antinutrients and in vitro protein and starch digestibilities of indigenously developed RWGT food mixture. Nutr Health 16: 173-181.

Solis B, Samartín S, Gómez S, Nova E and Marcos A 2002. Probiotics as a help in children suffering from malnutrition and diarrhoea. Europ J Clin Nutr 56: 57-59.

TORREJAIS MM, NATALI MRM, CONEGERO CI AND MIRANDA NETO MH. 1995. Effects of proteic malnutrition after breast-feeding on the morphology if the intestinal wall and myenteric neurons of the ileum of rats. Revta Unimar 17: 315-327.

VERDU EF. 2009. Probiotics effets on gastrointestinal function: beyond the gut? Neurogastroenterol Motil 21: 477-480.

Villena J, RACEdo S, AgÜERo G AND Alvarez S. 2006. Yoghurt accelerates the recovery of defence mechanisms against Streptococcus pneumonia in protein-malnourished mice. Brit J Nutr 95: 591-602.

VITERI FE AND SCHNEIDER MD. 1974. Gastrointestinal alterations in protein-calorie malnutrition. Sym Gastr Phys 58: 1487-1505.

WATERLOW CJ. 1996. Malnutrition proteico-energetica. Washington: Organización Panamericana de la Salud, 489 p.

Zanato JAF, Lui JF, Oliveira MC, CaValcante-Neto A, JUNQUEIRA OM, MALHEIROS EB AND SCAPINELlO C. 2008. Digestibilidade de dietas contendo antibiótico, probiótico e prebiótico para coelhos em crescimento. Biotemas 21: 131-136.

ZANIM STM, MOLINARI SL, SANT'ANA DMG AND MIRANDA Neto MH. 2003. Neurônios NADH-diaforase positivo do jejuno de ratos adultos (Rattus norvegicus) desnutridos. Arq Neuropsiquiatr 61: 650-653. 